Lee, R.B. (March 1992). Art, science, or politics? The crisis in hunter-gatherer studies. American Anthropologist 94(1), 31-54. 


\section{Art, Science, or Politics? The Crisis in Hunter- Gatherer Studies}

In the complex history of hunter-gatherer studies, several overlapping and at times antagonistic discourses can be discerned. However, one critique has emerged that would render all huntergatherer discourses irrelevant and do away with the concept altogether. The paper explores the poststructuralist roots of this "revisionism" and then argues why the concept of hunter-gatherer continues to be politically relevant and empirically valid. However, if they are to fulfill their promise of illuminating an increasingly fragmented and alienating modernity, hunter-gatherer studies will have to become more attuned to issues of politics, history, context, and reflexivity.

$\mathrm{H}$ UNTER-GATHERER STUDIES HAVE HAD a rather stormy history. The field has always been marked by controversy, and even the concept of hunter-gatherers itself has waxed and waned in importance. There have been periods in the history of anthropology when the very concept was tabooed, others when it was popular. Within the discipline today, the idea of hunter-gatherer has radically different receptions. Some see it as totally absurd, a derivative of outmoded evolutionary theory, while others see it as an eminently sensible category of humanity with a firm anchor in empirical reality. I noted a strong tendency toward the latter view at the Sixth Conference on Hunter-Gatherers (CHAGS) at Fairbanks, May-June 1990. At least no one advocated canceling the sixth CHAGS for lack of subject matter.

Even if it is agreed that hunters and gatherers exist, almost everything else about them is a matter for contestation. While some fields have crystallized a canon, there is no danger of that in hunter-gatherer studies; the field remains as fractious and controversyprone as ever. And in recent years a new element has been added to the many voices within the field, a body of opinion that would call into question the entire enterprise and abolish the concept of hunter-gatherers altogether. It would be hard to imagine a more fundamental challenge. Therefore, the purpose of this article is to define the range of anthropological practices that constitute hunter-gatherer studies today and to explore the roots-social, ideological, and epistemological-of the field's crisis in representation.

Some of these difficulties become apparent at the outset when we try to define what we mean by hunter-gatherers. ${ }^{1}$ Economically we are referring to those people who have historically lived by gathering, hunting, and fishing, with minimal or no agriculture and with no domesticated animals except for the dog. Politically gatherer-hunters are usually labeled as "band" or "egalitarian" societies in which social groups are small, mobile, and unstratified, and in which differences of wealth and power are minimally developed.

Obviously there is a degree of fit between "forager" subsistence strategies and "band" social organization, but the fit is far from perfect. Strictly economic definitions of foragers will include a number of peoples with ranking, stratification, and even slavery-the Northwest Coast groups-while the notion of "egalitarian bands" will include a number of small-scale horticultural and pastoral societies-in Amazonia, for example, and some Siberian "small peoples." 
Recent attempts to clarify these ambiguities have led to the useful distinction between "generalized" and "complex" hunter-gatherers (Price and Brown 1985; see also Woodburn's immediate/delayed return distinction [1980], and Testart 1988). It is the first category-peoples who hunted and gathered and who were organized into egalitarian bands-that will be the main focus of this discussion, though both simple nonforagers and complex foragers will be referred to from time to time.

The fluctuating fortunes of hunter-gatherer studies are tied as well to ambiguities that lie at the root of the field of anthropology itself; not the least of which revolves around the much debated concept of the primitive. Many would argue along with Stanley Diamond (1974:118) that the "search for the primitive" is the heart of anthropology's unique role in the human sciences. And much of the history of hunter-gatherer studies is linked to our multifaceted understandings of the primitive, either in Diamond's sense, in the quest for origins and fundamentals, or in what Lévi-Strauss terms anthropology's deeper purpose "to bear testimony to future generations of the ingeniousness, diversity, and imagination of our species" (1968:349).

But for other anthropologists the preoccupation with the primitive is an anachronism. For some the primitive is an illusion, an arbitrary construction of the disembodied "other" divorced from history and context (e.g., Clifford 1983; Sperber 1985; Wagner 1981). The result of this ambiguity is that there is a body of opinion in anthropologynot unconnected to views in other disciplines about "the end of history" and particularly among postmodernists - which would find anthropology's preoccupation with the primitive an acute embarrassment; as a consequence, the concept of hunter-gatherers becomes moot (Wilmsen 1989:xi-xviii, 1-6).

A second area of ambiguity is the nature of the anthropological enterprise itself. Anthropology has never declared itself unequivocally on the matter of whether it is a particularizing, historical discipline interested in understanding unit cultures, or whether it is a generalizing, nomothetic science searching for the broadest possible explanatory frameworks. Hunter-gatherer studies broadly defined has vigorous adherents of both these tendencies, going right back to Boas $(1935,1966)$ and Kroeber (1925) exemplifying the first tendency, and Steward $(1936,1938)$ and Radcliffe-Brown $(1922,1931)$ the second.

The history of hunter-gatherer studies, especially since the "Man the Hunter" conference in 1966 (Lee and DeVore 1968), illustrates both anthropology's ambiguities and the problematic role of hunter-gatherer studies within it. Among the persistent issues of the 1970s, 1980s, and 1990s have been debates on the following:

1. Evolutionism. The use and misuse of hunter-gatherer data to understand the fossil record and/or the evolution of human behavior has long been a contentious issue, as has been the concept of evolutionism itself. Hunter-gatherer studies have tended to enjoy respectability among some evolutionists (Isaac 1978; Lancaster 1978; Tanner and Zihlman 1976) and to be viewed with suspicion by others (Wobst 1978; Foley 1988).

2. Optimal Foraging Strategies. Modelers of the behavioral ecology of hunter-gatherers have continued to advocate a nomothetic research strategy and to refine quantitative methodologies at a time when much of the field was moving in the opposite direction. It has been the focus of notable research (Winterhalder and Smith 1981; Hawkes, Hill, and O'Connell 1982; Hill and Hawkes 1983) but also of some pointed critiques (Keene 1983; Martin 1983).

3. Woman the Gatherer. Feminist agendas and priorities have entered hunter-gatherer discourse initially through the ecological issue, raised in "Man the Hunter," of whether women's work in gathering plant foods is not more important to subsistence than men's hunting. This has led to a number of books and articles on gender, women's work, and women's power in foraging society. A significant segment of feminist anthropology has drawn heavily on hunter-gatherer studies (Slocum 1975; Begler 1978; Dahlberg 1981; Hunn 1981; Leacock 1981; Sacks 1979; Tanner and Zihlman 1976).

4. World View and Symbolic Analysis. Studies of the systems of meaning that give shape and coherence to hunter-gatherer identity and cosmology have been increasingly 
in evidence as a countercurrent to and implicit critique of the predominant ecological orientation of much of hunter-gatherer studies (Myers 1986b; Ridington 1990; Brody 1981; Endicott 1979).

5. Hunter-Gatherers in Prehistory. Archeologists have always had a strong interest in hunter-gatherer ethnography and its uses for interpreting the past (Binford 1978; Yellen 1977; Keene 1991). Currently, archeological interest in foragers exceeds by a wide margin interest by social and cultural anthropologists. Increasingly, archeologists are working directly with contemporary gatherer-hunters under the rubric of ethnoarcheology, and the questions archeologists ask are often quite different from the problematics within which social anthropologists work (Binford 1980; Paynter 1989; Yellen 1990; Wiessner 1982).

6. Hunter-Gatherers in History. The links of foraging peoples with the wider world, both in the present and in the past, have been a growing focus stimulated in part by world-systems analysis and by the publication of Wolf's Europe and the Peoples without History (1982; see also Schrire 1984; Wilmsen 1988, 1989; Headland and Reid 1989). One effect of this move toward historicizing has been to call into question the very idea of hunter-gatherers, and to argue seriously that they are a noncategory, a construction of the observers.

\section{Two Cultures, or Three, or Four?}

What analytical frameworks would be most useful and productive in sorting out the complex currents and countercurrents in the study of hunting and gathering peoples today? It might be helpful to recall C. P. Snow's famous essay, "The Two Cultures" (1959), in which he explored the eternal conflict between two irreconcilable academic subcultures: the humanistic and the scientific. ${ }^{2}$ In the first, scholarship was devoted to the study of meanings and interpretations in great works of art and literature. In the second, scholarship was dedicated to systematic and rigorous investigation of natural laws and general principles governing the natural and human world.

Anthropology is an apt example of a discipline that finds itself straddling the boundaries of C. P. Snow's two cultures. Within the discipline today there is a powerful current moving toward the view of anthropology as essentially a humanistic, even literary discipline, where truth, apart from the poetic variety, is unattainable. An equally strong current moves in the opposite direction, embracing the promise and moral authority of science and strengthening its commitment to improved techniques of data collection and measurement, coupled with more (not less) rigorous application of theory. The first sees itself as modeled after literature and literary criticism, the second draws its inspiration from theoretical biology and evolutionary ecology as well as an updated and recharged structural-functionalism. ${ }^{3}$

Within hunter-gatherer studies, the struggles and contradictions between the humanistic and scientific cultures are played out in a number of ways. While the scientists are gathering data for the construction of mathematical models of forager predator-prey behavior, the humanists, working sometimes among the same people, are collecting life histories of elders and recording and interpreting cosmologies and religious beliefs.

But there is a third culture embedded in current anthropological practice. This school sees neither humanistic nor scientific discourses as adequate to account for the past, present, and future of anthropological subjects. Raising issues of context and history, and placing foragers in regional systems, some scholars focus on the overriding issue of the relations of foragers with the world system. I will call this the "culture" of political economy.

The first anthropological perspective draws its inspiration from the interpretivist, structuralist, and hermeneutic traditions of Clifford Geertz (1973), Claude Lévi-Strauss (1963), Mary Douglas (1966), Victor Turner (1969), and James Clifford (1988; Clifford and Marcus 1986); the second from the positivist and adaptationist current of Julian Steward (1936, 1938), Lew Binford (1978, 1980), and others (e.g., Harris 1979); and the 
third from the critical Marxist tradition in which Eric Wolf and Sidney Mintz are situated (Wolf 1982; Mintz 1985; Leacock 1981; see also Roseberry 1989, Patterson and Gailey 1987). Each approach has a distinctive methodological stance and each has made important contributions to hunter-gatherer studies. In fact, however much one may profess allegiance to one or another of the three cultures, in practice elements of all three approaches are frequently employed in contemporary research projects (for a classic example of synthesis, see Sahlins 1968).

My first intention in writing this paper was to give a critical appraisal of research contributions to hunter-gatherer studies from each of the anthropological traditions. But a prior question must be addressed, an issue that poses a challenge to the entire collective enterprise so fundamental that to ignore it would be to fiddle while Rome burns. ${ }^{4}$ Following the lead of Foucault, Derrida, and the French poststructuralists, several anthropologists have declared hunter-gatherers a noncategory, a construction of observers mired in one or another brand of romantic idealism. The claims of this group are so farreaching and so ill-contained within the paradigm space of the three cultures that they could be said to constitute a fourth culture rendering irrelevant large parts of the other three.

Revisionism, as it has been called, combining some elements of political economy with some elements of poststructuralism, presents a fundamental challenge to the way that anthropologists have looked at hunter-gatherers for the past 30 years. It posits that foragers are not what they appear to be; and it proposes a drastic rethinking of our subject. Schrire poses the revisionist challenge in these terms:

There can be no doubt that, one way or another, all [ethnographies of hunter-gatherers] describe societies coping with the impact of incursions by foreign forces into their territories. . . The big question that arises is, are the common features of hunter-gatherer groups, be they structural elements such as bilateral kinship systems or behavioral ones such as the tendency to share food, a product of interaction with us? $\Lambda$ re the features we single out and study held in common, not so much because humanity shared the hunter-gatherer life-style for $99 \%$ of its time on earth, but because the hunter-gatherers of today, in searching for the compromises that would allow them to go on doing mainly that, have reached some subliminal consensus in finding similar solutions to similar problems? [1984:18]

And Wilmsen, writing of the Kalahari San, puts it this way:

the current status of the San-speaking peoples on the rural fringe of $\Lambda$ frican economies can be accounted for only in terms of the social policies and economies of the colonial period and its aftermath. Their appearance as foragers is a function of their relegation to an underclass in the playing out of historical processes that began before the current millennium and culminated in the early decades of this century. The isolation in which they are said to be found is a creation of our view of them, not of their history as they lived it. This is as true of their indigenous material systems as it is of their incorporation in wider spheres of political economy of southern $\Lambda$ frica. [1989:3, emphasis added]

There are two components to the revisionist critique, and it is essential to recognize the distinction between them. First there is the argument from history (see, e.g., Myers 1988:262-264; Headland and Reid 1989) that accuses past ethnographers of misreading or ignoring history and political economy and hence of treating the society in question as more bounded, more isolated, and more pristine than it really is. Political-cconomic revisionism argues that foragers have been integrated into larger regional or even international structures of power and exchange for so long that they can reveal nothing about the hunter-gatherer way of life. Evidence of trade and political domination is cited in support of this thesis. Linked to this line of critique is the purported discovery in huntergatherers of relations of domination and wealth accumulation previously associated with class societies (Price and Brown 1985; Flanagan 1989; Legros 1985). ${ }^{5}$

These critiques raise important issues, yet in terms of method, the argument remains on familiar terrain: one examines the historical, archeological, or other data and tests the merits of competing hypotheses against these data. Were the hunter-gatherers in question 
isolated? What does archeology reveal? What is the most parsimonious explanation for the observed facts? This is what Jacqueline Solway and I did in a recent Current Anthropology article titled "Foragers, Genuine or Spurious" (1990), meeting the issues raised by revisionists with empirical data that refuted their position.

The poststructuralist criticism, by contrast, takes a much more radically skeptical line. This view, linked to some versions of postmodernism, to deconstruction, and to a variety of other current schools, argues that there is no truth, only regimes of truth and power, and that all anthropology is powerfully shaped by the cultural constructions of the observer. Thus, ethnographic writing (about foragers or anybody else) has more in common with the historical novel and other works of fiction than it has with a scientific treatise. Therefore, the task of ethnography becomes immeasurably more problematic; truth is at best partial, flawed, obscured, and above all relative. ${ }^{6}$

This argument has radical implications for methodology. The production of knowledge has left the realm of empirical investigation and analytical methods of the past can no longer be relied upon. One can no longer utilize, for example, the etic/emic distinction because science after all is really only "Western emic" (Marcus and Fischer 1986:180 181). The use of Occam's Razor or the law of parsimony to choose between the merits of two competing explanations is no longer admissible because all are "true" at some level.

What impact does this have on the study of foragers? Political economists and poststructuralists have tended to make the same critique of ethnographic practice, but as we shall see, for rather different reasons. Both argue the extraordinary proposition that the natives are "Us," and both put into question the assumption that hunter-gatherers, whatever they may be, represent the "Other." The political economists argue that the natives are to all intents like Euro-Americans, because relations of domination and/or merchant capital reached the Arctic or the Ituri Forest or Sarawak long before ethnographers did and, therefore, tributary or mercantilist or capitalist relations of production have transformed foragers into people like ourselves, as parts of larger systems with hierarchies, commodities, exploitation, and other inequities and all their accompanying social consequences (Schrire 1984:18). Poststructuralists take the view that because anthropologists (like everyone else) are prisoners of their own ideology, as a consequence they can see in the "other" only a flawed perception of themselves. Thus, in either scenario, the "other" is declared a noncategory.

If the revisionist/poststructuralist position merits serious consideration-and the sheer volume of journal articles on these topics suggests that it does-then a major tenet of anthropology from Boas forward-that anthropology is the study of difference-becomes untenable. Or if "difference" is to be preserved as an anthropological problematic, then anthropology becomes the study of difference mutually constructed by powerful masters and powerless subalterns within a single world system.

In what follows I will explore the roots of the curious proposition that the natives are only different in surface features and that in truth they are "us." I see it as a peculiar expression of the intellectual culture of Late Capitalism. Anthropological revisionism lies at the intersection of two major tenets of contemporary Western thought: Proposition 1Nothing is real; and Proposition 2-The "system" is all-powerful.

\section{Nothing Is Real}

We live in an era in which the line between real and nonreal has become dangerously blurred. What is real has become a scarce commodity and the pursuit of the "real" sometimes becomes a desperate search. Under capitalism, as Marshall Berman (quoting Marx) titles his book, "all that is solid melts into air" (1983). We don't have to search far for evidence of this proposition. The Disney corporation produces and distributes in a single fiscal year, perhaps in a single week, more fantasy material to more people than entire archaic civilizations could produce in a century. States of the Left, Right, and Center and their bureaucracies also produce prodigious volumes of fantasy, and through ad- 
vertising and other media elites deploy enormous manipulative power (Ewen 1976). A recent ad for cigarettes (typical of the thousands that bombard Euro-Americans daily) has a picture of a carefully posed professional model, turned out as a fashion photographer, pretending to photograph another professional model herself posing, surrounded by other posed models in postures of forced gaiety. The caption: "Real People/Real Taste."

To protect the psyche from this type of assault, consumers and citizens in the West (and East) can be forgiven for erecting a shell of cynicism as a survival strategy under conditions of extreme debasement of the currency of reality. In fact it is hard to imagine keeping your sanity by any other means. This position of cool detachment and ironic distanciation has been considered the hallmark of the "postmodern condition" (Lyotard 1984; Sloterdijk 1987; Jameson 1984).

The world of scholarship has not escaped these massive social and psychological forces. In The Invention of Tradition (1983) Hobsbawm and Ranger and others show how allegedly hallowed customs handed down from the past are in fact the product of recent history. In his method of deconstruction, Derrida has argued that history is akin to a literary text and, like all texts, is ultimately unknowable $(1976,1978)$. It seems a short step to extending a critical and debunking discourse to all anthropological subjects.

But along the way there has been a slippage. The tools of deconstruction, developed to debunk and call into question the high and mighty, are now being applied to the powerless. Where the invention-of-tradition perspective was initially deployed to deconstruct the public rituals of the 19th-century British monarchy or pomp and circumstance in colonial India, it was now being generalized to question the claims to authenticity of small peoples. In his influential work, The Predicament of Culture, James Clifford shows how the Mashpee Indians construct their identity de novo in order to meet the exigencies of a court case (Clifford 1988). Similar arguments (but with less sympathy for the subalterns) have been made for the Maori by Hanson (1989) and for the ancient Hawaiians by Bergendorff, Hasager, and Henriques (1988; see also the reply by Sahlins 1989). ${ }^{7}$

The situation within anthropology is paralleled by the impact of poststructuralism on the broad front of the social sciences. Foucault's famous dictum (1976a, 1976b) that there is no truth, only regimes of truth and power, was originally intended as a critique of arbitrary power, but by showing the fragility of all truth-claims it has had the effect of undermining the legitimacy as well of oppositional movements for justice against these same powers (Taylor 1984; Habermas 1987).

There is a kernel of truth to the idea that all societies in the world are products of interaction with other societies and world society. Modern ethnography is a product of the Enlightenment and is a form of practice in which members of our academic subculture observe the other; as the late Kathleen Gough reminded us, anthropology is a child of imperialism. And then there are cases like the Philippine Tasaday, where a perfectly reasonable Southeast Asian semi-hunter-gatherer group, of which many examples exist, was seized on by the National Geographic and other media and popularized as the "Lost Stone Age" find of the century. Their recent exposure, and the media circus surrounding them, certainly fuels the cynicism that is itself the source of postmodernist sensibilities (Lee 1992; see also Dumont 1988; Berreman 1991; Duhaylungsod and Hyndman 1992).

Nevertheless, to succumb to the enticements of the poststructuralists or revisionists would be a disaster. Where I part company with the poststructuralists is in the view that our knowledge of the other-being filtered through perceptions, language, and cultureis so suspect that subjects can only be provisionally and arbitrarily constructed. It is striking how the largely male, White, and Western poststructuralists are proclaiming the death of the subject, precisely at the moment when alternative voices-women, people of color, Third World and aboriginal peoples-are struggling to constitute themselves as subjects of history, as the makers of their own history (Mascia-Lees, Sharpe, and Cohen 1989; see also Spivak 1988). 
I do not believe that anthropologists are nearly so powerless before the awesome task of representing the other's reality, or that the ethnography of the 1960s or 1970s was so flawed that it has to be discarded. Adam Kuper, in a recent critique of postmodernism, points out that the methodologies of the 1960s were not so very different from those of the present ${ }^{8}$ and that their results were subjected to the critical scrutiny of peer review and comparative evidence. Kuper argues, and I would agree, that the view that ethnographic writing is more akin to fiction than it is to science does not accord with the history of the discipline. If the ethnographers of that not-so-distant era had passed their fiction off as science their readership and their peers would not have stood for it (Kuper 1990). (For other critiques of "postmodernism" that attempt to reconstruct the "realist" foundations of social science epistemologies see Mascia-Lees, Sharpe, and Cohen 1989; Roth 1989; Sangren 1988; Gellner 1988; Lovibond 1989; Soper 1991; see also Bhaskar 1979, 1986.)

Strictly speaking, the position taken by poststructuralists is not that nothing is real, since all take as given the existence of the power elite, of the state and its bureaucracies, and of the world system and its awesome power and reach. Therefore it would be more accurate to represent Proposition 1 as "Nothing is real . . except power," which brings us directly to the second of our Propositions.

\section{The "System" Is All-Powerful}

The core proposition, "nothing is real," is reinforced by and reacts synergistically with the proposition, "the 'system' is all-powerful." We are living through a time in which history is accelerated; as the modern system continues to grow, things are moving faster and faster. Events and processes that unfolded over centuries are compressed into decades or years, and what transpired on a scale of years now unfolds in the space of months or weeks (Piel 1972:17-48; Harvey 1985:6-35). We need to put the revisionist debate in the context of this recent history.

Not everyone within hunter-gatherer studies has paused to reflect on the titanic forces that are transforming the world before our eyes. The era of Late Capitalism is witnessing the accumulation of capital on an unprecedented scale, the rise of the multinational corporation, and the phenomenal growth of the state as an apparatus for shaping and controlling human behavior (Chomsky 1989; Hardison 1989). In addition, one must try to comprehend the accelerating and expanding networks of information transfer on a world scale. Through television, e-mail, modems, cellular phones, fax, and other technologies it is possible to touch any part of the world in seconds, and through these same media we can dispose of all the world's accumulated knowledge and images with the push of a button-what Frederic Jameson has called "a decentered global network of microcircuits and blinking lights."

It is not surprising that this power of instantaneous communication, combined with the vast output of the culture industries mentioned above, and the centralizing power of the state, leads to fantasies of omniscience and omnipotence for the small minority of the world's population that has access to such tools (Berman 1983). Late Capitalism consumes the past with amazing rapidity, spews it out with such dizzying speed that it has the effect of obliterating the past, including the past of even 20 years ago. ${ }^{9}$ All these processes tend to endow the force of capitalism with a mystique of enormous reach and totalizing power. ${ }^{10}$

Externally, the spread of worldwide capitalism, sporadic and localized in the 18th century, a flood in the 19th and early 20th century, has become a veritable avalanche in the last third of the 20th century. ${ }^{11}$ As John Bodley, Shelton Davis, and others have pointed out, the world's tribal peoples are sitting directly in the path of the world's largest multinational corporations (Bodley 1982, 1988; Davis 1977; see also Jorgensen 1990). The scale of this penetration has increased in many cases by orders of magnitude in 10 or 20 years. To take an example, when I first arrived in Maun, Botswana, in 1963 there was a single tour operator taking tourists into the Okavango Swamps. Today there are over 80 
operators; many of them offer to take clients to the last of the River Bushmen, a man who now gets "discovered" 40 or 50 times a year. The Dobe area in 1963-64 was even more isolated than the Okavango Swamps. In that era it received one motor vehicle visit every four to six weeks, for a total of 9 to 13 vehicles per year. In 1987 I counted a vehicle every four to six hours for an annual total of 1,400 to 2,100, a one- to two-hundredfold increase. Tom Headland notes that at the turn of the century there were 500 agriculturalists in the vicinity of his Agta communities in northeastern Luzon. Today there are 30,000 (personal communication, 1990).

The Penan (or Punan) of Sarawak carried on regular long-distance trade with the coastal Dyak for hundreds of years; the impact of this trade on Penan institutions is the subject of another intense revisionist debate (Hoffman 1986; Brosius 1988). ${ }^{12}$ But whatever their links to the coast may have been historically, they are nothing compared to the impact of the Japanese multinationals clear-cutting the rain forest at a rate faster than that in the Amazon. The Penan are now fighting for their lives as the multinationals, in conjunction with the state government (many of whose ministers hold logging concessions), clear-cut the Penans' traditional foraging areas, leaving them destitute and forcing them into government resettlement schemes. The Penan have mounted roadblocks to stop the bulldozers, and hundreds of Penan have been arrested, but the logging goes on (Burger 1990:94-95; Colchester 1989; CBC 1990; see also Hong 1987). Similar examples could be drawn from virtually any part of the First, Second, or Third Worlds. This is the context of accelerating and massive change in which the field of hunter-gatherer studies is situated, and this is the source of the crisis of representation that the field is undergoing.

The point I want to emphasize is that fieldworkers who arrive in the $1980 \mathrm{~s}$ and $1990 \mathrm{~s}$ and observe these appalling conditions find it unbelievable that 30,20 , or even 10 years earlier, observers could have found societies with band structure, kinship, and subsistence patterns still functioning. Instead of reflecting on the magnitude of the changes in that 10 - or 20-year period, these revisionists immediately assume that the earlier studies were wrong and they go on to blithely project the contemporary patterns of destruction or outside domination back into the past.

Universalizing the present is the obverse of the equally flawed history that postulates pristine hunter-gatherers roaming the forest the year before the anthropologist arrives. While the latter view has correctly come in for a wave of criticism, it could be argued that the revisionists' willingness to project the present onto the past indicates an enchantment with the power of Capital that is, at base, no less romantic and uncritical than the muchcriticized enchantment with the pristine or primitive other.

\section{Mythologizing Pre-Revisionist Ethnography}

It would be foolish to argue that studies of hunters and gatherers prior to, say, 1970 were above reproach and therefore immune to criticism. Just as it would be equally foolish to argue that prior to 1970 all hunter-gatherers lived a pristine existence. Scholars working in that era made mistakes, and that includes myself. My own thinking has undergone continual reassessment, and it might be appropriate at this point to dispel some of the myths that have grown up about exactly what Kalahari ethnographers stand for.

One misconception is that pre-revisionist ethnographers believed the San were pristine hunter-gatherers (Wilmsen 1989:3, 6, 10, 33-43ff.; Wilmsen and Denbow 1990:503-507). But as early as 1965 I pointed out that the great majority of the ethnic San - about $80 \%$ were herders or farmers, or were existing as clients or servants on Black cattle posts and on commercial ranches (Lee 1965:20). Also in the 1960s I wrote in detail about the impact on the Dobe !Kung of European hunters and traders going back to the 1870s (Lee 1965:53-68).

A second myth concerns the notion that despite recognizing changes elsewhere, ethnographers have maintained a vision of the Dobe !Kung as unchanging in the face of overwhelming evidence to the contrary (e.g., Wilmsen and Denbow 1990:520; Gordon 
1984). At all stages of fieldwork Kalahari ethnographers have grappled with this issue and have tried to give a scrupulous accounting of the non-!Kung elements present in the Dobe area, including the Herero presence, the Tswana presence, and the "European" presence. Any illusions I might have harbored about !Kung pristine conditions were dispelled by the late 1960s when new information came to light. When it became apparent, for example, that the actual economic circumstances of the !Kung had been misread, I was at pains to correct first impressions (note that even in 1976 the word "pristine" appears in quotation marks):

As our field work continued, a more realistic picture of the "pristine" nature of the Dobe Area began to emerge. Most of the men of the Dobe area had had some experience at some point in their lives of herding the Bantu cattle, and about 20 percent of the young men were working on the cattle at any one time. Some had even owned goats or cattle in the past. Similarly the !Kung were not total strangers to agriculture. Many had learned the techniques by assisting their Bantu neighbors in planting, and in years of good rainfall some had planted small plots themselves and had harvested crops. [1976:18]

Far from holding a rigid and unchanging view of hunter-gatherers, there is evidence that many (but not all) students of the subject have changed their thinking over the years, and these changes have taken the field away from the position of the 1960s: that studies of contemporary hunter-gatherers are primarily a tool for understanding the evolution of human behavior. Two of these changes in particular are worth noting.

Recognizing that foragers have coexisted with farmers sometimes for centuries, yet have remained foragers, has moved a number of scholars toward a much more complex understanding of the historical position of foragers. Some of the same evidence that led revisionists to discard the very concept of hunter-gatherers led the editors and authors of Politics and History in Band Societies (Leacock and Lee 1982:1-20) in a different direction. The book was structured around the argument that hunter-gatherers can only be understood by seeing how some of them have been involved with farmers for a long time yet have retained their cultural identity. ${ }^{13}$

Understanding hunter-gatherer ecology, however important, is not enough. One has to look at the internal dynamics and the articulation of this internal system with wider histories. This has led to a second change in the thinking of a number of anthropologists, a shift away from an emphasis on hunting and gathering as modes of subsistence, toward the broader concept of "communal mode of production."

\section{From Subsistence Ecology to Mode of Production}

As I have discussed elsewhere (Lee 1981, 1988, 1990), communal relations of production are a widespread and well-documented phenomenon. Yet, despite their ubiquity, the subject has been woefully undertheorized. Communal relations of production are observed among the !Kung as well as among a number of hunter-gatherers in a wide variety of historical settings. They are also found among peoples with mixed economies of foraging and horticulture, such as the Iroquois (Trigger 1987, 1990), the Sharanahua (Siskind 1980), and the Batek (Endicott 1979). They are found even among former foragers in peripheral capitalism, such as aboriginal fringe dwellers in Darwin, Australia (Sansom 1980). ${ }^{14}$

Accepting the existence of communal relations of production in diverse settings among foragers and (some) nonforagers, the next question is how this is to be explained. I find it extremely difficult to accept that all these diverse instances are to be seen, as revisionists have argued, strictly as societal impoverishment resulting from exploitation by larger and more powerful societies (Schrire 1984:18; Gordon 1984:220; Wilmsen 1983, 1989).

The explanation lies, rather, in one remarkable organizational principle shared by band societies and peoples like them: the ability to reproduce themselves while limiting the accumulation of wealth and power. Such societies operate within the confines of a metaphorical ceiling and floor: a ceiling above which one may not accumulate wealth and 
power and a floor below which one may not sink. These limits on both aggrandizement and destitution are maintained by powerful social mechanisms known as leveling devices (Lee 1990:242-245). Such societies therefore have social and political resources of their own and are not just sitting ducks waiting to adopt the first hierarchical model that comes along. Clastres (1989) said it best when he said that for these kinds of societies the main problem was resisting becoming a state; by this he meant resisting not only the imposition of a state from outside but also resisting the pressures building up within, pressures leading toward accumulation and concentration of wealth and power.

Clastres did not imply that the nonstate societies lived in a state of perfect equality, nor would I. Hunter-gatherers may exhibit differences in wealth and power and they are certainly not nonviolent. ${ }^{15}$ I prefer to follow the argument developed by Harriet Rosenberg in her recent research on !Kung aging and caregiving (1990). Rosenberg uses the term "entitlement" to account for the ways in which !Kung elderly were cared for by relatives and nonrelatives alike, such that no one, not even childless people, would be denied access to support in old age. This was part of a general phenomenon in !Kung society in which everyone claimed and was recognized as being "entitled" to the necessities of life, by right of being a member of the society.

!Kung elders do not see themselves as burdens. They are not apologetic if they are not able to produce enough to feed themselves. They expect others to care for them when they can no longer do so. Entitlement to care is naturalized within the culture. Elders do not have to negotiate care as if it were a favor; rather it is perceived as a right. [Rosenberg 1990:29]

\section{Will the "Real" San Please Stand Up?}

The Kalahari revisionists claim to be restoring the San to history, but it is a curious view of history that the only way you can historicize foragers is to make them into pastoralists (or serfs) in the past! This seems to be an instance of life imitating art-of granting all agency to the dominating society whether capitalist or tributary, and making the histories of these diverse societies entirely reactive. ${ }^{16}$ Solway and I (1990) have shown that while some San peoples did become peasants and serfs of Black overlords, others did not. The !Kung San of the Dobe area lay outside of the main routes of trade and spheres of tributary power. They defended their lands against incursions from Blacks and Whites, and when they entered into client relations with Black patrons they did so on terms that were more favorable than that prevailing in other parts of the Kalahari. The result is that when systematic ethnographic study began in the 1950s and 1960s, observers found a society with a number of key institutions-language, kinship, ritual practices-intact, while other institutions-land tenure, dispute settlement, political dynamics-were clearly in a state of flux (Marshall 1976; Lee and DeVore 1976; Lee 1979; Shostak 1981; Solway and Lee 1990; Yellen 1977).

Why did these distinctive institutions persist? They should not be seen simply as holdovers or survivals from the past kept in place by the weight of tradition. This trivializes their significance. These institutions are essential elements of cultural survival and they must be reproduced anew in each generation. Their presence is as good an index as any of the cultural viability and vitality of peoples like the !Kung. ${ }^{17}$

What is at issue here is whether foragers broadly represent a diverse but nevertheless identifiable form of human society with characteristic social and economic properties, or whether the foragers' identity dissolves and merges with that of serf, servant, client, slave, or rural proletariat.

What is the !Kung view of their own history? The !Kung see themselves as a people, increasingly circumscribed and threatened, but a people nonetheless with a strong sense of themselves. When told that they were really tributary appendages, long integrated into the economies of their more powerful neighbors, they were surprised and not a little offended. ${ }^{18}$ 


\section{History and Identity of Hunter-Gatherers: Two Views}

This brings us to two views of history and identity. One starts from cultural difference and postulates that there are cultures out there, which exist independent of academic constructions of them; for hunter-gatherers there is a lived reality regardless of whether or not they trade or render tribute to their neighbors. The other view sees historical status as constituted only by membership in a regional trading bloc, by subject status in a chiefdom or state, or by the production of a commodity for exchange; in other words, historical visibility can only be achieved through a relationship with other systems. The question that arises is whether that part of their history is the only thing or even the main thing that we want to know about hunter-gatherers.

Leacock and I (1982) argued that foraging societies can only be understood as the product of a triple dynamic: first, the internal dynamic of communal foraging relations of production; second, the dynamics of their historical interactions with farmers, herders, and states; and third, the dynamic of articulation and incorporation within the modern world system. The difference between this position and the revisionist one is the latter's privileging the operation of the second and third dynamics at the expense of the first. The revisionist position accords minimal reality to foraging as a distinct mode of life, what Tim Ingold (1990:130) has recently called "a radically alternative mode of relatedness." 19

These two views of hunter-gatherers inscribe alternate discourses about the current conjuncture. The first says we are living in a time when the world is young, in flux, and still in the process of formation; some of the antecedent societal forms are still there to be observed and experienced. The people we have come to call hunter-gatherers are examples, to varying degrees, of alternative ways of life, examples of difference. The other discourse says no, the world is old, what you are seeing is not difference, it is just another aspect of us, created by the same forces, the same "system" that created us. In my view this second discourse contains a number of unexamined assumptions about the transformative power of commodities, and about the ability of mercantile and tributary systems to project their power and to impose their will on the peoples on their periphery. ${ }^{20}$

How will we ever sort out the conflicting claims of the differing schools of thought in hunter-gatherer studies? Given the enormous load of ideology in hunter-gatherer studies, along with most branches of scholarship, I want to reiterate a plea for the importance of empirical evidence; I am as much opposed to mindless empiricism as anyone, but without empirical evidence debates will disintegrate into ideological name-calling.

What is urgently needed in this era of disillusion is the middle path: a working discipline that sees science, humanism, and critical reflection as three components of a single field; scholars need empiricism tempered by reflexivity and a dialectic between the two. All of this should be framed within a sense of history and political economy, to ensure that a scholar's situated history and the relationship between scholar and subject are not lost. Scholars must interrogate assumptions as the poststructuralists suggest, but after that, I for one would like to get on with it. If sound methods demonstrate that huntergatherers are historically serfs or pastoralists or whatever, then so be it. But the current crop of revisionist arguments are dubious, to say the least. ${ }^{21}$ The task of situating huntergatherers historically has barely begun, and there remains a great deal of scope for archeological, ethnographic, and ethnohistoric investigations to resolve the question of to what degree hunter-gatherers can be said to be culturally autonomous or integrated into larger systems at various points in their histories. ${ }^{22} \mathrm{I}$ also suggest that these questions will motivate the production of the kinds of knowledge that will be used by future generations, sifted and resifted long after the debates of this decade fade into the past.

To recover a link to the real world, to empirical reality, is precisely what some scholars tried to do in the 1960s with the work diaries, demography, subsistence ecology, and careful ethnography (e.g., Helm 1965; Hiatt 1965; Marshall 1961; Rose 1960). This is a scholarly tradition that many are carrying on today, while constantly improving their meth- 
ods. But empiricism, however critically informed, is not the whole story. Self-definitions change. In the 1960s, many anthropologists saw themselves as crusading empiricists, replacing speculation with facts, but it is now possible to recognize that, like all scholars in the human sciences, the ethnographers of the 1950s and 1960s were also storytellers, weavers of narratives (after all, the origin of the word "text" is from "textiles"). It was not only a question of what they had to say but also how they said it. To this extent those who emphasize anthropology's affinities to literature $d o$ have a point. ${ }^{23}$

As Donna Haraway has noted (1989), one of the master narratives constructed (in part) from hunter-gatherer data has been the story of human nature and life in the "state of nature": who we are as a species, our past, and by implication our future. The poststructuralist project focuses our attention almost exclusively on the "constructedness" of these narratives. But just because they are constructed doesn't mean that they have no claim to empirical validity or that the search for knowledge of the past is an illegitimate enterprise. Ethnographic analogy to the past does involve leaps of extrapolation and therefore must be treated with extreme caution, but the archeological record can and does provide direct knowledge of the distant past.

The problem remains, however, that like ethnography archeological interpretations of the past are no less shaped by the ideological forces of the present. This highlights the critical need for maintaining and enlarging the sphere of knowledge-in both archeology and ethnography - that transcends the ideological battles of each era: the need for a version of anthropology that is both critical and empirical (cf. O'Meara 1989; Carrithers 1990).

Given the difficulties of living up to the demands of doing this kind of work and the many pitfalls, it is surprising how much good work is being done in hunter-gatherer studies. Rejecting the view of foragers as timeless primitives or as rural proletarians, there are those who would see hunting and gathering as a way of life that exists in the present yet is different from Western urban modes of life. To varying degrees these students attempt to maintain a sense of balance and proportion between the reality of their scholarly world and the reality of their subjects, and between the methodological demands of the three cultures. ${ }^{24}$

One trend that seems to be present in all three methodological currents is a move by some (but by no means all) away from seeing hunting and gathering peoples as objects of anthropological inquiry, to a situation in which they become the subjects of their own history and often the directors of their own research. This has paralleled the development of political consciousness among indigenous people. As foragers and former foragers have become more involved in struggles for their rights, hunter-gatherer studies have become much more of a collaborative enterprise: working with the people in their struggles to determine their futures. ${ }^{25}$

Perhaps the most significant development of the last decade is indigenous peoples speaking to us in their own voices; for example, the Canadian Innu, Lubicon, TemeAugama, and others in Richardson (1989). The Gitksan and Wet'suet'en people of British Columbia are good examples of former (and continuing) foragers who have addressed the larger public directly in a variety of voices and settings, including the courts (Sterritt 1989; People of 'Ksan 1980; Gisday Wa and Delgum Uukw 1989). Increasingly, indigenous peoples are making political alliances with environmentalists, feminists, youth groups, and peoples of color.

On this new and expanded political terrain an interesting question concerns how hunters and gatherers themselves regard hunter-gatherer studies. Clearly the cultural renaissance under way in a number of native communities has generated considerable interest in "traditional" ethos and world view, governance, subsistence, arts, crafts, ethnobotany, and healing; for these and other spheres of knowledge, the elders and anthropological texts are the main sources of information. ${ }^{26}$ 


\section{Conclusion}

This article has delineated the crisis of representation in hunter-gatherer studies and has attempted to comprehend the underlying epistemological and ideological roots of the crisis. The field of hunter-gatherer studies has been undergoing a series of transformations and the original raison d'être has required reassessment. Yet, despite the fundamental challenges of the "revisionists," it can be argued that a core of relevance to both scholarly and indigenous peoples' agendas remains in hunter-gatherer studies; that the field is responding to this challenge is indicated by the shift away from simplistic evolutionary arguments toward more nuanced, historically sensitized, and critical understandings. In this respect the altered contours of hunter-gatherer studies represent a successful incursion by humanists and political economists on a terrain that had been largely dominated by natural-science-oriented methods and philosophies.

In the preface to Man the Hunter, DeVore and I wrote, "We cannot avoid the suspicion that many of [the contributors] were led to live and work among the hunters because of a feeling that the human condition was likely to be more clearly drawn here than among other kinds of societies" (Lee and DeVore 1968:ix). I now believe this is wrong. The human condition is about poverty, injustice, exploitation, war, suffering. To seek the human condition one must go, as Wolf and Hansen (1975) did, to the barrios, shantytowns, and palatial mansions of Rio, Lima, and Mexico City, where massive inequalities of wealth and power have produced fabulous abundance for some and misery for most. When anthropologists look at hunter-gatherers they are seeking something else: a vision of human life and human possibilities without the pomp and glory, but also without the misery and inequity of state and class society.

Almost all of humanity lives today in highly organized bureaucratized societies of enormous scale and systematic inequalities. Hunter-gatherers, in spite of the inducements (or threats?) to become incorporated, choose for whatever reasons to resist and to live lives very different from that of the majority. The pace is slower, technology simpler, numbers smaller, inequality less, and the relationship to land and resources-the sense of placeis on a radically different basis. Following Clastres, I have argued that what sets huntergatherers apart is their ability to reproduce themselves while severely limiting the accumulation and concentration of wealth and power. This feature they share with a number of simple horticultural and pastoral societies. Since the accumulation of wealth and power (and resistance to it) is the driving force of much of human history, it follows that societies that don't have this dynamic must have a dynamic of a different sort: what Tim Ingold has called a "different kind of sociality" (1990:130-131).

If indigenous peoples want to adopt a Western (or Soviet) way of life, the door is open; in fact, the pressures to conform are immense. The fact that this has not happened, that some foragers still pursue alternative lifeways not in isolation but in full awareness of alternatives, is a persuasive argument against the two propositions that framed the present essay. There is something out there beyond the reach of the world system (capitalist or otherwise). The "system" is powerful but not omnipotent. Pockets of resistance persist and show us that even in this hard-bitten postmodern age other ways of being are possible.

Since so many of the world's intractable problems derive from the gigantic maldistribution of wealth and power, it stands to reason that societies that can reproduce themselves without exploitation have a great deal to teach us. As the world's peoples struggle to redefine alternative visions in the aftermath of the Cold War, I am convinced that hunter-gatherer studies, far from being the fantasy projection of uncritical romantics, have a role to play: in the movement for justice for indigenous peoples, and as part of a larger movement to recapture wholeness from an increasingly fragmented and alienating modernity. 


\section{Notes}

This paper was presented at the Sixth International Conference on Hunting and Gathering Societies (CHAGS), Fairbanks, Alaska, May 27-June 1, 1990, and is published here with permission of the CHAGS organizing committee, chaired by Linda Ellanna. The author would like to thank the following colleagues and friends for useful input in the development of this paper: Michael Asch, Victor Barac, John Barker, Alan Barnard, Liz Cashdan, Julie Cruikshank, Richard Daly, Pat Draper, I. Eibl-Eibesfeldt, Bion Griffin, Matthias Guenther, Henry Harpending, Bob Hitchcock, Tim Ingold, Dick Katz, Tom Patterson, Nick Peterson, Phillip Smith, Harriet Rosenberg, Jackie Solway, Eric Smith, Verna St. Dennis, Polly Wiessner, Eric Wood, and John Yellen. These critics are not responsible, of course, for any errors of fact or interpretation. Versions of this paper have been presented at seminars at the Universities of British Columbia, Victoria, Simon Fraser, and Washington. Critical comments by colleagues and students at these institutions were instrumental in further clarifying the issues presented here.

${ }^{1}$ Whether hunter-gatherers are more accurately called gatherer-hunters to acknowledge the predominance of gathered foods over game is an issue I have addressed in detail elsewhere (Lee 1979). The term "foragers" is an economical shorthand that does not prejudge the issue either way (e.g., Lee 1981).

'Snow's position in turn can be traced back to a 19th-century critical Romanticism, which saw science as providing an ideological basis for the spread and destructive effects of capitalism. (I thank Victor Barac for this observation.)

${ }^{3}$ The first draft of this paper had been completed before I became aware of Michael Carrithers's (1990) article, which also develops the figure of the "two cultures" as a means of comprehending contemporary anthropology.

${ }^{4}$ While work from this perspective still constitutes only a small fraction of hunter-gatherer research, it would be a serious error to ignore, as many within the field have, its profound implications, not only for researchers but, more important, for the anthropological subjects themselves.

${ }^{5}$ For a thoughtful and balanced discussion of this issue see Paynter 1989.

"For a late conversion to relativism see Leach 1989; on the fallacy of "hyperrelativism" see Trigger 1989.

${ }^{7}$ Wilmsen uses the Hobsbawm and Ranger thesis to the same effect in a section of his book entitled "The Invention of 'Bushmen'" (1989:24-26).

${ }^{8} \Lambda \mathrm{s}$ a case in point, Wilmsen, after stating that his "book is . . not an ethnography" and proclaiming the end of "the ethnographic era of anthropology" (1989:xii), goes on to devote several hundred pages to the presentation of "ethnographic" data on the San in the form of ethnohistory, genealogies, demography, economic anthropology, and subsistence ecology.

'David Lowenthal (1985) has offered a provocative discussion of how both selective cultural amnesia and an obsession with the past characterize contradictory contemporary views of history.

${ }^{10}$ The feeling of omniscience and instant global communication was nowhere more clearly expressed than in the television coverage of the first days of the war in the Persian Gulf, where major developments were seen as they occurred during North American prime time.

${ }^{11}$ Many of these ideas are drawn from the works of Ernest Mandel (1978), Fred Jameson (1984), and the thought of Marshall MacLuhan.

${ }^{12} \mathrm{Hoffman}$ has argued, like Wilmsen, that the Penan were locked into the coastal trade centuries ago and had long since become subjects of coastal suzerains. Brosius and others have made the case for a greater degree of Penan autonomy.

${ }^{13} \mathrm{Of}$ this volume Bender and Morris write: "The publication of Politics and History in Band Societies $\ldots$ demolish [ed] the notion that contemporary gatherer-hunter societies were in any sense 'pristine" " (1988:6). A similar point is made by John Wright (1989:535) and by Donna Haraway (1989:194-197, 227), who clearly locates Lee as a member of the "revisionists." The revisionists for their part seem to prefer to retain a 1960s image of hunter-gatherer studies as a more convenient straw-person.

${ }^{14}$ Some would argue, along with Phillip E. L. Smith, that communal relations and other aspects of foraging lifeways can be discerned in frontier European populations like the transhumant English settlers in Newfoundland from the 18th century on (Smith, personal communication, 1991).

${ }^{15}$ For example, the appearance of slavery in complex foraging societies like those of the Northwest Coast (Donald 1983), and of other forms of inequality elsewhere (e.g., Legros 1985; Flanagan 1989), need to be seriously studied. And Clastres's own treatment of several topics-for one, gender-leaves much to be desired.

${ }^{16}$ Bender and Morris in their introduction to Volume 1 of Hunters and Gatherers (Ingold, Riches, and Woodburn 1988a) perceptively make a similar critique of the revisionist view of history (1988:7-14): 
Above all the message of [Politics and History in Band Societies] must be that gatherer-hunters have their own history. An understanding of the processes of encapsulation has to work in tandem with an understanding that gatherer-hunter variability, past or present, has an internal dynamic. Change in gatherer-hunter societies does not wait upon the arrival of land-hungry farmers, nor upon capitalist penetration. [1988:13-14]

${ }^{17}$ Having said this, there is still room to accommodate Alan Barnard's (1988) arguments that ethnicity and identity of San peoples are constructed in part from their mutual accommodations and antagonisms with other peoples.

${ }^{18}$ Not only is the assertion of their "subjugation" vehemently denied by the !Kung themselves, but their view of the timing of the entrance of non-!Kung into their lands directly contradicts the "revisionist" position. When !Kung elders were asked to identify which of their African neighbors-the Hereros, Tswanas, or BaYei-first came into their land, they insisted it was none of them: the Europeans came first, followed by other Africans (Solway and Lee 1990:115). Since the Europeans only arrived in the 1870s, this renders moot the revisionist argument that the !Kung of the Dobe area were subjugated in the lst millennium $\Lambda$.D. !Kung oral histories of the colonial period are presented in Lee (1991).

${ }^{19}$ In fact, Ingold has argued that hunter-gatherer sociality is of such a different order that the term "society" is inappropriate with reference to them and should be reserved for describing postforager peoples (1990:130-131).

${ }^{20}$ In the Kalahari, for example, there are a number of problems in applying 20th-century patterns of power-holding and projecting them back into the past of the Dobe !Kung. For over $90 \%$ of the centuries of San/Black interaction, the putative overlords were not capitalists or even mercantilists, but African kin-ordered and tributary formations. In order for the revisionist model to work in this prehistoric context one has to endow 1st- and 2nd-millennium chiefdoms (if that is what they were) with the same predatory impulses and the same ability to exercise power across great distances that the historic Tswana chiefdoms briefly possessed in the 19th century, under the intense pressure of the Boer military threat and the competition of the British traders and imperialists. Despite the claims of the revisionists (e.g., Wilmsen and Denbow 1990:449-503), there is no convincing evidence that any group in what is now northwestern Botswana had that kind of power before the late 19th century, least of all the Tawana chiefdom, the weakest of the eight major tribes that made up the Tswana nation (Tlou 1985).

${ }^{21}$ For a critique of revisionist historiography in the Kalahari see Lee and Guenther (1991).

${ }^{22}$ For two excellent examples of how this can be done see Trigger (1990) and Hunn (1990).

${ }^{23}$ As I wrote in 1979:

Modern anthropology no longer believes that the scientist of culture is neutral: today's epistemology includes the observer along with the "natives" in the field of view. When acknowledged and used creatively the observer's likes and dislikes, his [sic] prejudices and enthusiasms, become an instrument of discovery, a part of the learning process itself and not external to it. [Lee 1979:8, emphasis in original]

${ }^{24}$ While an inventory of recent work in hunter-gatherer studies is far beyond the scope of this paper, a few examples from two of the "paradigms" are appended to illustrate the abundance of work in the 1980s and 1990s (see also Note 23).

"Scientists": Ingold (1986a, 1986b), Woodburn (1980, 1982, 1988), and Wiessner (1982); Winterhalder (1990), Smith (1988); see also Winterhalder and Smith (1981); Smith and Boyd (1990), Vierich (1982), Cashdan (1987, 1990), Griffin (1989), Kent (1989), and the Harvard Pygmy project (Bailey and Peacock 1988, Bailey et al. 1989).

"Humanists": Brody (1981), Myers (1986b), Ridington (1990), Shostak (1981), Cruikshank (1991), Bird-David (1990). For some interesting recent work on Western perceptions and constructions of hunter-gatherers see Dumont (1988), Sponsel (1992), Armitage and Kennedy (1989); see also Myers (1986a). (For various combinations of all three paradigms see Ingold, Riches, and Woodburn [1988a, 1988b].)

${ }^{25}$ This renegotiated ethnographic ethic can be seen clearly in the work of some of the "political economists": Asch (1984), Chance (1990), Daly (1988), Duhaylungsod and Hyndman (1992), Feit (1985, 1991), Hitchcock (1977, 1988), Hitchcock and Brandenburgh (1990), Hunn (1990), Kidd (1990), Peterson (1982, 1985), Peterson and Matsuyama (1991), Sansom (1985), and Tanner (1979). Special mention should be made of the work of Megan Biesele and John Marshall, who have been working with the !Kung San of Namibia through the most dramatic changes in their history (Biesele and Weinberg 1990). 
${ }^{26} \mathrm{On}$ this score I found it instructive that so many members of indigenous Alaskan organizations endorsed the 1990 Fairbanks Conference on Hunting and Gathering Societies, not only contributing papers and workshops but also supporting CHAGS financially. These sponsors included Bering Straits Native Corporation, NANA Regional Corporation Inc., Interior Fish Processors of Alaska, and the Interior Mayors' Association of Alaska.

\section{References Cited}

Armitage, Peter, and J. C. Kennedy

1989 Redbaiting and Racism in Labrador and Quebec. Canadian Review of Sociology and Anthropology 18(4):798-817.

Asch, Michael

1984 Home and Native Land: Aboriginal Rights and the Canadian Constitution. Toronto: Methuen.

Bailey, R., and N. Peacock

1988 Efe Pygmies of Northeast Zaire: Subsistence Strategies in the Ituri Forest. In Uncertainty in the Food Supply. G. A. Harrison and A. Boyce, eds. Pp. 88-117. Cambridge: Cambridge University Press.

Bailey, R. C., G. Head, M. Jenike, B. Owen, R. Rechtman, and E. Zechenter

1989 Hunting and Gathering in Tropical Rain Forest: Is It Possible? American Anthropologist 91:59-82.

Barnard, Alan

1988 Cultural Identity, Ethnicity and Marginalization among the Bushmen of Southern Africa. In New Perspectives on the Study of Khoisan. Rainer Vossen, ed. Pp. 9-27. Hamburg: Helmut Buske Verlag.

Begler, E.

1978 Sex, Status, and Authority in Egalitarian Society. American Anthropologist 80:571-588.

Bender, Barbara, and Brian Morris

1988 Preface. In Hunters and Gatherers, Vol. 1: History, Evolution and Social Change. T. Ingold, D. Riches, and J. Woodburn, eds. Pp. 4-14. London: Berg.

Bergendorff, Steen, Ulla Hasager, and Peter Henriques

1988 Mythopraxis and History: On the Interpretation of the Makahiki. Journal of the Polynesian Society 97:391-408.

Berman, Marshall

1983 All that is Solid Melts into Air. New York: Simon and Schuster.

Berreman, Gerald

1991 The Incredible "Tasaday": Deconstructing the Myth of a "Stone-Age" People. Cultural Survival Quarterly 15(1):3-46.

Bhaskar, Roy

1979 The Possibility of Naturalism: $\Lambda$ Philosophical Critique of the Human Sciences. Brighton, UK: Harvester Press.

1986 Scientific Realism and Human Emancipation. London: Verso.

Biesele, Megan, and Paul Weinberg 1990 Shaken Roots: The Bushmen of Namibia. Johannesburg: EDA Publications.

Binford, Lewis R.

1978 Nuniamiut Ethnoarchaeology. New York: Academic Press.

1980 Willow Smoke and Dogs' Tails: Hunter-Gatherer Settlement Systems and Archaeological Site Formation. American Antiquity 45:4-20.

Bird-David, Nurit

1990 The Giving Environment: Another Perspective on the Economic System of GathererHunters. Current Anthropology 31(2):189-196.

Boas, Franz

1935 Kwakiutl Culture as Reflected in Mythology. New York: Memoirs of the American Folklore Society, 28.

1966 Kwakiutl Ethnography. Helen Codere, ed. Chicago: University of Chicago Press.

Bodley, John

1982 Victims of Progress. Menlo Park, CA: Cummings.

1988 Tribal Peoples and Development Issues: A Global Overview. Mountain View, CA: Mayfield. 
Brody, Hugh

1981 Maps and Dreams. Harmondsworth: Penguin.

Brosius, Peter

1988 A Separate Reality: Comments on Hoffman's The Punan: Hunters and Gatherers of Borneo.

Borneo Research Bulletin 20(2):81-105.

Burger, Julian

1990 The Gaia Atlas of First Peoples: A Future for the Indigenous World. New York: Doubleday.

Carrithers, Michael

1990 Is Anthropology Art or Science? Current Anthropology 31:263-282.

Cashdan, Elizabeth

1987 Trade and Its Origins on the Botetli River. Journal of Anthropological Research 43:121138.

1990 [ed.] Risk and Uncertainty in Tribal and Peasant Economies. Boulder, CO: Westview Press.

CBC (Canadian Broadcasting Corporation)

1990 The Fate of the Forest. Toronto: CBC “Ideas" Programme Transcript.

Chance, Norman $\Lambda$.

1990 The Inupiat and Arctic Alaska: An Ethnography of Development. Fort Worth, TX: Holt, Rinehart and Winston.

Chomsky, Noam

1989 Necessary Illusions: Thought Control in Democratic Societies. The Massey Lectures. Montreal: CBC Enterprises.

Clastres, Pierre

1989 Society against the State: Essays in Political Anthropology. New York: Zone Books.

Clifford, James

1983 On Ethnographic Authority. Reflections 1:118-145.

1988 The Predicament of Culture: Twentieth Century Ethnography, Literature, and Art. Cambridge, MA: Harvard University Press.

Clifford, James, and George Marcus, eds.

1986 Writing Culture: The Poetics and Politics of Ethnography. Berkeley: University of California Press.

Colchester, Marcus

1989 Pirates, Squatters and Poachers: The Political Ecology of Dispossession of the Native Peoples of Sarawak. London and Kuala Lumpur: Survival International and INSAM Malaysia.

Cruikshank, Julie

1991 Life Lived Like a Story: Lifestories of Three Yukon Native Elders. Lincoln: University of Nebraska Press.

Dahlberg, Frances, ed.

1981 Woman the Gatherer. New Haven, CT: Yale University Press.

Daly, Richard

1988 Land Ownership among British Columbia First Nations. Paper presented to First Nations Land Ownership Conference, Vancouver, B.C., Justice Institute, Oct. 1988.

Davis, Shelton

1977 Victims of the Miracle: Development and the Indians of Brazil. New York: Cambridge University Press.

Derrida, Jacques

1976 Of Grammatology. Baltimore, MD: Johns Hopkins University Press.

1978 Writing and Difference. Chicago: University of Chicago Press.

Diamond, Stanley

1974 In Search of the Primitive: $\Lambda$ Critique of Civilization. New Brunswick, NJ: Transaction Books.

Donald, Leland

1983 Was Nuu-chah-nulth-aht (Nootka) Society Based on Slave Labor? In The Development of Political Organization in Native North America. Elisabeth Tooker, ed. 1979 Proceedings of the American Ethnological Society. Pp. 108-119. Washington, DC: American Ethnological Society.

Douglas, Mary

1966 Purity and Danger. New York: Praeger. 
Duhaylungsod, Levita, and David Hyndman

1992 Behind and Beyond the Tasaday: The Untold Struggle over Resources of Indigenous Peoples. In The Tasaday Controversy. Tom Headland, ed. Washington, DC: American Anthropological Association Special Publication. (In press.)

Dumont, Jean-Paul

1988 The Tasaday, Which and Whose? Towards the Political Economy of an Ethnographic Sign. Cultural Anthropology 3:261-275.

Endicott, Kirk

1979 Batek Negrito Religion. Cambridge: Cambridge University Press.

Ewen, Stuart

1976 Captains of Consciousness: Advertising and the Social Roots of Consumer Culture. New York: McGraw-Hill.

Feit, Harvey

1985 Legitimation and Autonomy in James Bay Cree Responses to Hydro-Electric Development. In Indigenous Peoples and the Nation-State. Noel Dyck, ed. Pp. 27-66. St. John's, Newfoundland: Memorial University Press.

1991 Gifts of the Land: Hunting Territories, Guaranteed Incomes and the Construction of Social Relations in James Bay Cree Society. In Cash, Commoditisation and Changing Foragers. N. Peterson and T. Matsuyama, eds. Senri Ethnological Studies No. 30. Pp. 223-268. Osaka: National Museum of Ethnology.

Flanagan, James

1989 Hierarchy in Simple "Egalitarian" Societies. Annual Review of Anthropology 18:245266.

Foley, Robert

1988 Hominids, Humans and Hunter-Gatherers: An Evolutionary Perspective. In Hunters and Gatherers, Vol. 1: History, Evolution and Social Change. T. Ingold, D. Riches, and J. Woodburn, eds. Pp. 207-221. London: Berg.

Foucault, Michel

1976a Truth and Power. In Power/Knowledge. C. Gordon, ed. (Reprinted in The Foucault Reader, P. Rabinow, ed., pp. 5I-75, Random House, 1984.) New York: Pantheon.

1976b The Archaeology of Knowledge. New York: Harper and Row.

Geertz, Clifford

1973 The Interpretation of Cultures: Selected Essays. New York: Basic Books.

Gellner, Ernest

1988 The Stakes in Anthropology. American Scholar 57:17-32.

Gordon, Robert

1984 The !Kung in the Kalahari Exchange: An Ethnohistorical Perspective. In Past and Present in Hunter-Gatherer Studies. Carmel Schrire. Pp. 195-224. Orlando, FL: Academic Press.

Griffin, P. Bion

1989 Hunting, Farming, and Sedentism in a Rain Forest Foraging Society. In Farmers as Hunters: Implications of Sedentism. Susan Kent, ed. Pp. 60-70. Cambridge: Cambridge University Press.

Habermas, Jürgen

1987 Modernity: An Incomplete Project. In Interpretive Social Science: A Second Look. Paul Rabinow and William M. Sullivan, eds. Pp. 141-156. Berkeley: University of California Press.

Hanson, Allan

1989 The Making of the Maori: Culture Invention and Its Logic. American Anthropologist 91:890-902.

Haraway, Donna

1989 Primate Visions: Gender, Race and Nature in the World of Modern Science. New York: Routledge, Chapman and Hall.

Hardison, O. B., Jr.

1989 Disappearing through the Skylight: Culture and Technology in the Twentieth Century. Baltimore, MD: Penguin.

Harris, Marvin

1979 Cultural Materialism: The Struggle for a Science of Culture. New York: Vintage.

Harvey, David

1985 Consciousness and the Urban Experience: Studies in the History and Theory of Capitalist Urbanization. Baltimore, MD: Johns Hopkins University Press. 
Hawkes, Kirsten, Kim Hill, and James O'Connell

1982 Why Hunters Gather: Optimal Foraging and the Ache of Eastern Paraguay. American Ethnologist 9:379-398.

Headland, Tom, and Lawrence Reid

1989 Hunter-Gatherers and Their Neighbors from Prehistory to the Present. Current Anthropology 30:43-66.

Helm, June

1965 Bilaterality in the Socio-Territorial Organization of the Arctic Drainage Dene. Ethnology $4: 361-385$.

Hiatt, Les

1965 Kinship and Conflict: A Study of an Aboriginal Community in Northern Arnhem Land. Canberra: Australian National University Press.

Hill, Kim, and Kirsten Hawkes

1983 Neotropical Hunting among the Ache of Eastern Paraguay. In Adaptive Responses of Native Amazonians. R. Hames and W. Vickers, eds. Pp. 139-188. New York: Academic Press.

Hitchcock, Robert

1977 Kalahari Cattle Posts. Gaborone: Government of Botswana.

1988 Monitoring Research and Development in the Remote Areas of Botswana. Gaborone: Government Printer.

Hitchcock, Robert, and Rodney Brandenburgh

1990 Tourism, Conservation and Culture in the Kalahari Desert, Botswana. Cultural Survival Quarterly 14:20-24.

Hobsbawm, Eric, and T. O. Ranger, eds.

1983 The Invention of Tradition. Cambridge: Cambridge University Press.

Hoffman, Carl

1986 The Punan: Hunters and Gatherers of Borneo. Ann Arbor: UMI Research Press.

Hong, Evelyne

1987 Natives of Sarawak: Survival in Borneo's Vanishing Forest. Pulau Pinang, Malaysia: Institut Masyarakat.

Hunn, Eugene

1981 On the Relative Contribution of Men and Women to Subsistence among Hunter-Gatherers of the Columbia Plateau: A Comparison with Ethnographic Atlas Summaries. Journal of Ethnobiology 1:124-134.

Hunn, Eugene, with James Selam and family

1990 Nch’i-Wána, "The Big River": Mid-Columbia Indians and Their Land. Seattle: University of Washington Press.

Ingold, Tim

1986a The Appropriation of Nature: Essays on Human Ecology and Social Relations. Manchester: Manchester University Press.

1986b Evolution and Social Life. Cambridge: Cambridge University Press.

1990 Comment on "Foragers, Genuine or Spurious: Situating the Kalahari San in History," by J. Solway and R. Lee. Current Anthropology 31:130-131.

Ingold, Tim, David Riches, and James Woodburn, eds.

1988a Hunters and Gatherers, Vol. 1: History, Evolution and Social Change. London: Berg.

1988b Hunters and Gatherers, Vol. 2: Property, Power and Ideology. London: Berg.

Isaac, Glynn

1978 The Food-Sharing Behavior of Protohuman Hominids. Scientific American 238(4):90108.

Jameson, Frederic

1984 Postmodernism, or the Cultural Logic of Late Capitalism. New Left Review 146:53-92.

Jorgensen, Joseph

1990 Oil-Age Eskimos. Berkeley: University of California Press.

Keene, Art

1983 Biology, Behavior, and Borrowing: A Critical Examination of Optimal Foraging Models in $A$ rchaeology. In Archaeological Hammers and Theories. A. Keene and J. Moore, eds. New York: Academic Press.

1991 Archeology and the Heritage of Man the Hunter. Reviews in Anthropology 16:133-147. 
Kent, Susan, ed.

1989 Farmers as Hunters: Implications of Sedentism. Cambridge: Cambridge University Press.

Kidd, Dorothy

1990 Ikajurti, The Helper: Midwifery in the Arctic (film). Ottawa: Inuit Broadcasting Corporation, and Pauktuutit, the Inuit Women's Association.

Kroeber, A. L.

1925 Handbook of the Indians of California. Washington, DC: Bureau of American Ethnology Bulletin No. 78.

Kuper, Adam

1990 Ethnographic Practice. Unpublished ms., Department of Human Sciences, Brunel University, Uxbridge, Middlesex, England.

Lancaster, Jane

1978 Carrying and Sharing in Human Evolution. Human Nature 1(2):82-89.

Leach, Edmund

1989 Review of Works and Lives, by C. Geertz. American Ethnologist 16:137-141.

Leacock, Eleanor

1981 Myths of Male Dominance. New York: Monthly Review Press.

Leacock, Eleanor, and Richard Lee, eds.

1982 Politics and History in Band Societies. Cambridge: Cambridge University Press.

Lee, Richard

1965 Subsistence Ecology of !Kung Bushmen. Doctoral dissertation in Anthropology, University of California, Berkeley. Ann Arbor: University Microfilms.

1976 Introduction. In Kalahari Hunter-Gatherers: Studies of the !Kung San and Their Neighbors. R. Lee and I. DeVore, eds. Pp. 3-24. Cambridge, MA: Harvard University Press.

1979 The !Kung San: Men, Women and Work in a Foraging Society. New York: Cambridge University Press.

1981 Is There a Foraging Mode of Production? Canadian Journal of Anthropology 2:13-19.

1988 Reflections on Primitive Communism. In Hunters and Gatherers, Vol. 1: History, Evolution and Social Change. T. Ingold, D. Riches, and J. Woodburn, eds. Pp. 252-268. London: Berg.

1990 Primitive Communism and the Origins of Social Inequality. In The Evolution of Political Systems: Sociopolitics in Small-Scale Sedentary Societies. Steadman Upham, ed. Pp. 225246. Cambridge: Cambridge University Press.

1991 Solitude or Servitude: !Kung Images of the Colonial Encounter. Paper presented in the symposium, "Narratives of Resistance: History, Ethnography and Power." Meetings of the Canadian Anthropology Society, London, Ontario, May 1991.

1992 Making Sense of the Tasaday. In The Tasaday Controversy. Tom Headland, ed. Washington, DC: American Anthropological Association Special Publication. (In press.)

Lee, Richard, and Irven DeVore, eds.

1968 Man the Hunter. Chicago: Aldine.

1976 Kalahari Hunter-Gatherers: Studies of the !Kung San and Their Neighbors. Cambridge, MA: Harvard University Press.

Lee, Richard, and Mathias Guenther

1991 Oxen or Onions: The Search for Trade (and Truth) in the Kalahari. Gurrent Anthropology 32. (In press.)

Legros, Dominique

1985 Wealth, Poverty, and Slavery among 19th Century Tutchone, Athapaskans. Research in Economic Anthropology 7:37-64.

Lévi-Strauss, Claude

1963 Structural Anthropology. New York: Basic Books.

1968 The Concept of Primitiveness. In Man the Hunter. R. Lee and I. DeVore, eds. Pp. 349352. Chicago: Aldine.

Lovibond, Sabrina

1989 Feminism and Postmodernism. New Left Review 178:5-28.

Lowenthal, David

1985 The Past Is a Foreign Country. Cambridge: Cambridge University Press.

Lyotard, Jean François

1984 The Postmodern Condition: A Report on Knowledge. Minneapolis: University of Minnesota Press. 
Mandel, Ernest

1978 Late Capitalism. London: New Left Books.

Marcus, George, and Michael Fischer

1986 Anthropology as Cultural Critique: An Experimental Moment in the Human Sciences. Chicago: University of Chicago Press.

Marshall, Lorna

1961 Talking, Sharing and Giving: Relief of Social Tensions among the !Kung Bushmen. Africa 31:231-249.

1976 The !Kung of Nyae Nyae. Cambridge, MA: Harvard University Press.

Martin, J.

1983 Optimal Foraging Theory: A Review of Some Models and Their Applications. American Anthropologist 85:612-629.

Mascia-Lees, Frances, Patricia Sharpe, and Colleen Ballerino Cohen

1989 The Post-Modernist Turn in Anthropology: Cautions from a Feminist Perspective. Signs 15(1):7-33.

Mintz, Sidney

1985 Sweetness and Power: The Place of Sugar in Modern History. New York: Viking Press.

Myers, Fred

1986a The Politics of Representation: Anthropological Discourse and Australian Aborigines. American Ethnologist 13:430-447.

1986b Pintupi Country, Pintupi Self: Sentiment, Place and Politics among Western Desert Aborigines. Washington, DC: Smithsonian Institution Press.

1988 Critical Trends in the Study of Hunter-Gatherers. Annual Review of Anthropology $17: 261-282$.

O'Meara, J. Tim

1989 Anthropology As Empirical Science. American Anthropologist 91:354-369.

Patterson, Tom, and Christine Gailey, eds.

1987 Power Relations and State Formation. Washington, DC: American Anthropological Association.

Paynter, Robert

1989 The Archaeology of Equality and Inequality. Annual Review of Anthropology 18:369399.

People of 'Ksan

1980 Gathering What the Great Nature Provided: Food Traditions of the Gitksan. Vancouver: Douglas and McIntyre.

Peterson, Nicholas

1982 Aboriginal Land Rights in the Northern Territory of Australia. In Politics and History in Band Societies. E. Leacock and R. Lee, eds. Pp. 441-462. Cambridge: Cambridge University Press.

1985 Capitalism, Culture and Land Rights. Social Analysis 18:85-101.

Peterson, Nicholas, and Toshio Matsuyama, eds.

1991 Cash, Commoditisation and Changing Foragers. Senri Ethnological Studies No. 30. Osaka: National Museum of Ethnology.

Piel, Gerard

1972 The Acceleration of History. New York: Knopf.

Price, T., and J. Brown, eds.

1985 Prehistoric Hunter-Gatherers: The Emergence of Social Complexity. Orlando, FL: Academic Press.

Radcliffe-Brown, A. R.

1922 The Andaman Islanders. Cambridge: Cambridge University Press.

1931 The Social Organization of Australian Tribes. Sydney: Oceania Monographs, 1.

Richardson, Boyce, ed.

1989 Drumbeat: Anger and Renewal in the Indian Country. Toronto: Summerhill Press/Assembly of First Nations.

Ridington, Robin

1990 Little Bit Know Something: Stories in a Language of Anthropology. Vancouver: Douglas and McIntyre. 
Rose, Frederick G. G.

1960 Classification of Kin, Age Structure and Marriage amongst the Groote Eylandt Aborigines: A Study in Method and Theory of Australian Kinship. Berlin: Akademie Verlag.

Roseberry, William

1989 Anthropologies and Histories: Essays in Culture, History, and Political Economy. New Brunswick, NJ: Rutgers University Press.

Rosenberg, Harriet G.

1990 Complaint Discourse, Aging, and Caregiving among the !Kung San of Botswana. In The Cultural Context of Aging. Jay Sokolovsky, ed. Pp. 19-41. New York: Bergin and Garvey.

Roth, Paul A.

1989 Ethnography without Tears. Current Anthropology 30:555-569.

Sacks, Karen

1979 Sisters and Wives. Urbana: University of Illinois Press.

Sahlins, Marshall

1968 Notes on the Original Affluent Society. In Man the Hunter. R. Lee and I. DeVore, eds. Pp. 85-89. Chicago: Aldine.

1989 Captain Cook at Hawaii. Journal of the Polynesian Society 98:371-423.

Sangren, Steven

1988 Rhetoric and the Authority of Ethnography: "Postmodernism" and the Social Reproduction of Texts. Current Anthropology 29:405-435.

Sansom, Basil

1980 The Camp at Wallaby Cross: $\Lambda$ boriginal Fringe Dwellers in Darwin. Canberra: Australian Institute of $\Lambda$ boriginal Studies.

1985 Aborigines, Anthropologists and Leviathan. In Indigenous Peoples and the Nation-State. Noel Dyck, ed. Pp. 67-94. St. John's, Newfoundland: Memorial University Press.

Schrire, Carmel

1984 Past and Present in Hunter-Gatherer Studies. Orlando, FL: Academic Press.

Shostak, Marjorie

1981 Nisa: The Life and Words of a !Kung Woman. London: Allen Lane.

Siskind, Janet

1980 To Hunt in the Morning. New York: Oxford University Press.

Slocum, Sally

1975 Woman the Gatherer. In Towards an Anthropology of Women. R. Reiter, ed. Pp. 36-50.

New York: Monthly Review Press.

Sloterdijk, Peter

1987 Critique of Cynical Reason. Minneapolis: University of Minnesota Press.

Smith, Eric A.

1988 Risk and Uncertainty in the "Original Affluent Society": Evolutionary Ecology of Resource-Sharing and Land Tenure. In Hunters and Gatherers, Vol. 1: History, Evolution and Social Change. T. Ingold, D. Riches, and J. Woodburn, eds. Pp. 222-251. London: Berg.

Smith, Eric A., and Robert Boyd

1990 Risk and Reciprocity: Hunter-Gatherer Socioecology and the Problem of Collective Action. In Risk and Uncertainty in Tribal and Peasant Economies. E. Cashdan, ed. Pp. 167-195.

Boulder, CO: Westview Press.

Snow, C. P.

1959 The Two Cultures and the Scientific Revolution. New York: Cambridge University Press.

Solway, Jacqueline, and Richard Lee

1990 Foragers, Genuine or Spurious: Situating the Kalahari San in History. Current Anthropology 31:109-146.

Soper, Kate

1991 Postmodernism, Subjectivity and the Question of Value. New Left Review 186:120-128.

Sperber, Dan

1985 On Anthropological Knowledge. New York: Cambridge University Press.

Spivak, Gayatri C.

1988 Can the Subaltern Speak? In Marxism and the Interpretation of Culture. Cary Nelson and Lawrence Grossberg, eds. Pp. 271-313. Urbana: University of Illinois Press.

Sponsel, Leslie

1992 Our Fascination with the Tasaday: Anthropological Images and the Image of Anthropology. In The Tasaday Controversy. Tom Headland, ed. Washington, DC: American $\Lambda \mathrm{n}$ thropological Association Special Publication. (In press.) 
Sterritt, Neil J.

1989 Gitksan and Wet'suwet'en: Unflinching Resistance to an Implacable Invader. In Drumbeat: Anger and Renewal in the Indian Country. B. Richardson, ed. Pp. 265-294. Toronto: Summerhill Press/Assembly of First Nations.

Steward, Julian

1936 The Economic and Social Basis of Primitive Bands. In Essays in Anthropology in Honor of A. L. Kroeber. R. H. Lowie, ed. Pp. 331-350. Berkeley: University of California Press.

1938 Basin-Plateau Aboriginal Sociopolitical Groups. Bureau of American Ethnology Bulletin No. 120. Washington, DC: Smithsonian Institution.

Tanner, Adrian

1979 Bringing Home Animals: Religious Ideology and Mode of the Production of the Misstassini Cree Hunters. London: Hurst.

Tanner, Nancy, and Adrienne Zihlman

1976 Women in Evolution 1: Innovation and Selection in Human Origins. Signs 1:585-608.

Taylor, Charles

1984 Foucault on Freedom and Truth. Political Theory 12(2):152-183.

Testart, Alain

1988 Some Major Problems in the Social Anthropology of Hunter-Gatherers. Current Anthropology 29:1-31.

Tlou, Thomas

1985 A History of Ngamiland 1750 to 1906: The Formation of an African State. Gaborone: Macmillan.

Trigger, Bruce

1987 The Children of Aetaentsic. Revised edition. Montreal: McGill-Queens University Press.

1989 Hyperrelativism, Responsibility and the Social Sciences. Canadian Review of Sociology and $\Lambda$ nthropology 26(5):776-797.

1990 Maintaining Economic Equality in Opposition to Complexity: An Iroquoian Case Study. In The Evolution of Political Systems: Sociopolitics in Small-Scale Sedentary Societies. Steadman Upham, ed. Pp. 109-146. Cambridge: Cambridge University Press.

Turner, Victor

1969 The Ritual Process. Chicago: Aldine.

Vierich, Helga

1982 Adaptive Flexibility in a Multi-Ethnic Setting. In Politics and History in Band Societies. E. Leacock and R. Lee, eds. Pp. 213-222. Cambridge: Cambridge University Press.

Wa, Gisday, and Delgam Uukw

1989 The Spirit in the Land: The Opening Statement of the Gitksan and Wet'suwet'en Hereditary Chiefs in the Supreme Court of British Columbia. Gabriola, BC: Reflections Press.

Wagner, Roy

1981 The Invention of Culture. Chicago: University of Chicago Press.

Wiessner, Polly

1982 Risk, Reciprocity and Social Influences on !Kung San Economics. In Politics and History in Band Societies. E. Leacock and R. Lee, eds. Pp. 61-84. Cambridge: Cambridge University Press.

Wilmsen, Edwin

1983 The Ecology of Illusion: Anthropological Foraging in the Kalahari. Reviews in Anthropology 10:9-20.

1988 We Are Here: The Politics of Aboriginal Land Tenure. Berkeley: University of California Press.

1989 Land Filled with Flies: A Political Economy of the Kalahari. Chicago: University of Chicago Press.

Wilmsen, Edwin, and James Denbow

1990 Paradigmatic History of San-Speaking Peoples and Current Attempts at Revision. Current Anthropology 31(5):489-524.

Winterhalder, Bruce

1990 Open Field, Common Pot: Harvest Variability and Risk Avoidance in Agricultural and Foraging Societies. In Risk and Uncertainty in Tribal and Peasant Economies. E. Cashdan, ed. Pp. 67-87. Boulder, CO: Westview Press.

Winterhalder, Bruce, and Eric A. Smith, eds.

1981 Hunter Gatherer Foraging Strategies: Ethnographic and Archeological Analyses. Chicago: University of Chicago Press. 
Wobst, Martin

1978 The Archaeo-Ethnology of Hunters and Gatherers, or, The Tyranny of the Ethnographic Record in Archaeology. American Antiquity 43:303-309.

Wolf, Eric R.

1982 Europe and the People without History. Berkeley: University of California Press.

Wolf, Eric, and Edward Hansen

1975 The Human Condition in Latin America. New York: Columbia University Press.

Woodburn, James

1980 Hunters and Gatherers Today and Reconstruction of the Past. In Soviet and Western Anthropology. E. Gellner, ed. London: Duckworth.

1982 Egalitarian Societies. Man (n.s.) 17:431-451.

1988 African Hunter-Gatherer Social Organization: Is It Best Seen as a Product of Encapsulation? In Hunters and Gatherers, Vol. 1: History, Evolution and Social Change. T. Ingold, D. Riches, and J. Woodburn, eds. Pp. 31-64. London: Berg.

Wright, John

1989 Review of Politics and History in Band Societies, edited by E. Leacock and R. Lee. Journal of Southern African Studies 15:535-536.

Yellen, John

1977 Archaeological Approaches to the Present. New York: Academic Press.

1990 The Present and Future of Hunter-Gatherer Studies. In Archaeological Thought in America. C. C. Lamberg-Karlovsky, ed. New York: Cambridge University Press. 